\title{
EDUCATION LEVEL OF CERTAIN ETHNIC GROUPS IN THE PROVINCE OF VOJVODINA (REPUBLIC OF SERBIA)
}

DOI: https://doi.org/10.18509/AGB.2021.11

UDC: $37.043 .1-054(497.113)$

\section{Milka Bubalo Živković, Tamara Lukić, Bojan Đerčan}

University of Novi Sad, Faculty of Sciences, Department of Geography, Tourism and Hotel Menagement, Trg Dositeja Obradović 3, Novi Sad, Republic of Serbia

corresponding author: miladin32dus@yahoo.com

submitted: 08.05.2020

accepted: 28.07 .2020

published: 10.10 .2020

\begin{abstract}
The Province of Vojvodina is an adequate area for investigating similarities and differences between certain ethnic groups, since there are large numbers of ethnic groups in the area, over 20. The analyses of ethnic groups have been conducted from various aspects, but this research focuses on education level dissimilarities. Due to the compulsory primary education law the population numbers with different education levels were slowly increasing and the illiterate and uneducated population numbers slowly decreased among all ethnic groups after the World War II. Thus the differences in education level decreased. Globalization process contributed to diminishing differences in cultural and educational level among different ethnic groups. However, there are still certain ethnic groups that resist global trends and outshine the others in terms of education level. The data of the Statistical Office of the Republic of Serbia have been statistically processed and the obtained results were analyzed and used for the estimation of the education level of certain ethnic groups. The analysis and estimation was conducted for the whole Province of Vojvodina, then for rural and urban areas as well as for the municipality level. The analyses of various levels showed certain differences for the same ethnic groups.
\end{abstract}

Keywords Education, Ethnic groups, Vojvodina Province, Serbia.

\section{INTRODUCTION}

The previous century and the beginning of this century were marked with frequent reforms of the education system in this area. It occurred both in Former Yugoslavia and since 2006 in the Republic of Serbia. All the reforms were aimed at increasing the level of education and in order to achieve the goal frequent concordances with the European and worldwide trends were made.

The reforms that were conducted in the last decade within the education system of the Republic of Serbia have a tendency of increasing the share of highly educated population in the total population, that being one of the prerequisites of joining the European Union. At the same time, the aim is also to eradicate the illiteracy or reduce it to the smallest percentage. A highly educated population is the indicator of the development level of a country. Investments in education and human resources create the capital that yields more economic benefits, which consequently leads to economic growth. Education increases human capital which increases productivity [1]. Education may have an impact on the increase in innovations. Moreover, it impacts the understanding and application of new technologies and processes which in return also spur economic growth.

The education level of the population in developing countries is different from the education level of the population in developed countries. The education level is not only the result of formal education. It is also influenced by family background and the environment [2].

Investments in education consequently increase the share of the population with higher education in the total population. The highly educated population has more opportunities and for easier and quicker employment as well as for higher economic income. An increase in the share of the highly educated population is the general aim which underpins the economic growth strategy and development in developed market economies. The low share of a highly educated population and high level of unemployment have been serious obstacles for the recovering process of the economy and more 
intensive increase and development of the economy in Serbia. However, certain changes have been reached by the year 2020. The share of the highly educated population has been slowly increasing and the share of the unemployed is decreasing (about $10 \%$ in 2019). The lowest unemployment rates in Serbia were in the Belgrade Region (7.6\%) and the Vojvodina Region (8.2\%). The other two regions (the Šumadija and West Serbia Region and the East and South Serbia Region) had the unemployment rates above $10 \%[3]$.

After the year 1970, there was an increase in the share of the highly educated population (population older than 15) in Serbia. The share increased from $1.7 \%$ to $9.0 \%$ by the year 2010 . Most of the neighbouring countries have a more favourable educational structure. In the same period (19702010) there was an increase in the highly educated population rate from $1.7 \%$ to $13.3 \%$ in Slovenia, and from $2.2 \%$ to $11.0 \%$ in Croatia. The rate of the highly educated population in Romania was $2.1 \%$ and in Bulgaria 5.0\% in 1970. By the year 2010, the percentage of the highly educated in Romania reached $6.6 \%$ and in Bulgaria, it reached $13.1 \%$ [4]. According to the OECD data for the year 2018, the countries with the highest percentage of the highly educated population (age group 25 to 64) were Luxembourg (43.0\%), Norway (43.0\%), Finland

\section{MATERIAL AND METHODS}

The education structure of the population has been explored in the Vojvodina Region, which is situated in the north of the Republic of Serbia. The data on the illiterate population and education levels of the population were obtained from the Statistical Office of the Republic of Serbia. The illiterate population is found among the population older than 10 and the

\section{EDUCATION STRUCTURE OF THE POPULATION IN VOJVODINA IN 2011}

In order for an individual to obtain further education levels, the individual has first to become literate. According to the population census in 2011, the share of the illiterate population was $1.96 \%$ in Serbia. During nine years prior to the 2011 census, a lot had been done to reduce the number of the illiterate population, since the share of the illiterate population was $3.45 \%$ in 2002 [7] [8]. The highest rate of the illiterate population is among the elderly population.

A certain number of the elderly population deceased in the observed period, which is one of the reasons for the reduced rate of the illiterate population in the total population. Among the ethnic groups with the constant large numbers of illiterate people are the Roma (19.9\%) and the Vlachs (11.1\%). The Roma are constantly facing
(43.6\%), Australia (43.7\%), United States of America (45.7\%), Great Britain (46.0\%), South Korea (47.0\%), Israel (50.0\%), Japan (50.5\%) and Canada (56.3\%) [5].

There are significant variations in the educational structure of the population in certain religious groups. Among those with the highest education level are the Jews, the Christians, the unaffiliated (atheists, agnostics), the Buddhists, and among the least educated religious groups are the Muslims and the Hindi [6].

There are also certain differences in education levels among the ethnic groups in particular countries. Such a situation is present in the countries which have the largest numbers of the highly educated population, such as the USA and Australia, which are facing the smaller percentage of the educated population among the autochthonous population on their territories Indians in the USA and Aborigines in Australia. There are also differences among certain ethnic groups in Serbia. The aim of this research is to determine which ethnic groups have the largest numbers of the highly educated population as well as which groups have higher shares of the population with only primary and only secondary education level achieved.

education level is analysed among the population older than 15. The data of the Statistical Office of the Republic of Serbia were additionally processed. Standard statistical methods were used in order to make easier comparisons and better insight into the educational structure of the population according to the population census in 2011 .

numerous problems both as a nation and also for their lifestyle. Poverty, discrimination, inadequate preparation for starting the school, poor knowledge of the language, insufficient motivation of the parents to provide education for their children, especially girls, inflexibility of the education system towards the needs of the Roma children are only a few factors that have impact on the majority of the Roma children not to complete primary education in the Republic of Serbia [9].

Even today, when the rate of the illiterate population has been reduced to less than $2 \%$, the illiterate population is found among younger age groups of the Roma population (Table 1). Also, larger numbers of illiterate population are found among the Hungarian population. However, this is the point where mimicry can be observed since a 
certain number of the Roma population declares themselves as Hungarians or Serbs. If this is taken into account, the percentage of the illiterate Roma population is significantly higher.

Table 1. Illiterate population aged 10 and above according to ethnicity and age groups in the Vojvodina Region. Source: [10]

\begin{tabular}{|c|c|c|c|c|c|c|c|c|}
\hline \multirow[b]{2}{*}{ Ethnic groups } & \multicolumn{7}{|c|}{ Illiterates } & \multirow{2}{*}{$\begin{array}{c}\% \text { of the } \\
\text { total } \\
\text { population }\end{array}$} \\
\hline & Total & $\begin{array}{l}10-14 \\
\text { years }\end{array}$ & $15-19$ & $20-34$ & $35-49$ & $50-64$ & $\begin{array}{c}65 \text { and } \\
\text { over }\end{array}$ & \\
\hline Serbs & 16230 & 185 & 266 & 907 & 739 & 1821 & 12312 & 1,5 \\
\hline Albanians & 23 & 0 & 1 & 4 & 4 & 4 & 10 & 1,3 \\
\hline Bosniaks & 5 & 0 & 0 & 0 & 0 & 0 & 5 & 0,7 \\
\hline Bulgarians & 11 & 0 & 0 & 0 & 1 & 3 & 7 & 0,8 \\
\hline Bunjevci & 98 & 3 & 0 & 9 & 15 & 22 & 49 & 0,7 \\
\hline Vlachs & 17 & 0 & 0 & 1 & 0 & 2 & 14 & 11,1 \\
\hline Goranci & 4 & 0 & 1 & 0 & 0 & 0 & 3 & 0,4 \\
\hline Yugoslavs & 54 & 1 & 3 & 4 & 2 & 13 & 31 & 0,5 \\
\hline Hungarians & 1621 & 39 & 51 & 216 & 224 & 310 & 781 & 0,7 \\
\hline Macedonians & 177 & 2 & 3 & 15 & 15 & 19 & 123 & 1,8 \\
\hline Muslims & 188 & 9 & 11 & 47 & 43 & 36 & 42 & 6,7 \\
\hline Germans & 35 & 0 & 0 & 0 & 3 & 4 & 28 & 1,2 \\
\hline Roma people & 5647 & 292 & 414 & 1474 & 1266 & 1473 & 728 & 19,9 \\
\hline Romanians & 723 & 16 & 30 & 110 & 123 & 223 & 221 & 3,3 \\
\hline Russians & 4 & 0 & 0 & 0 & 1 & 0 & 3 & 0,4 \\
\hline Ruthenians & 54 & 1 & 4 & 10 & 6 & 10 & 23 & 0,4 \\
\hline Slovaks & 251 & 8 & 5 & 37 & 42 & 46 & 113 & 0,6 \\
\hline Slovenians & 7 & 0 & 1 & 0 & 0 & 1 & 5 & 0,4 \\
\hline Ukrainians & 71 & 1 & 2 & 3 & 2 & 4 & 59 & 1,9 \\
\hline Croats & 571 & 1 & 11 & 31 & 26 & 58 & 444 & 1,3 \\
\hline Montenegrins & 178 & 0 & 0 & 9 & 9 & 14 & 146 & 0,9 \\
\hline Czechs & 7 & 0 & 0 & 0 & 2 & 2 & 3 & 0,6 \\
\hline Other & 133 & 5 & 5 & 37 & 30 & 25 & 31 & 2,9 \\
\hline Did not declare & 1005 & 28 & 29 & 122 & 151 & 240 & 435 & 1,6 \\
\hline Regional affiliation & 94 & 2 & 1 & 8 & 10 & 16 & 57 & 0,4 \\
\hline Unknown & 615 & 8 & 9 & 93 & 152 & 193 & 160 & 5,5 \\
\hline
\end{tabular}

The smallest numbers of the illiterate are recorded among the Gorani, the Russian, the Ruthenian, and the Slovene populations. The rate of the illiterate population for all the above mentioned ethnic groups is only $0.4 \%$ and without the illiterate population among younger age groups.

If we observe the population aged 15 and above in Serbia, it may be noticed that the dominating population is the population with secondary education levels both for males and females (Table $2)$. The indicators of poor educational structure in Serbia are these data - Serbia has $2.7 \%$ population without any education (as well as the $11.0 \%$ of the population with unfinished primary school. It is mainly the Romani population.

One in ten is highly educated among the population 15 and above in Serbia. Higher education has 5.7\% of the 15 and above population. If we observe urban and rural environments we can notice significant differences. In a rural environment, there are more people without any education, more people without completed primary education, and more people with secondary education.

However, in an urban environment, there are more people with high or higher education. The urban environment has five times more population with completed high education.

In the Belgrade Region, there is the highest share of the population with high education. The share of the population with high education for Vojvodina Region is significantly lower and even lower for the Region Šmadija and West Serbia and the South and East Serbia Region.

On the other hand, there is the lowest share of those with uncompleted primary education and those who only completed primary education in the Belgrade 
Region. The population with completed secondary education is dominant in Vojvodina and Belgrade
Regions, whereas in the South Serbia Region it is less dominant (Table 2).

Table 2. Population aged 15 and above according to the nation and educational background in the Republic of Serbia and its regions. $\mathrm{t}$ - total; $\mathrm{m}$ - male; $\mathrm{f}$ - female. Source: [7] [10]

\begin{tabular}{|c|c|c|c|c|c|c|c|c|c|}
\hline $\begin{array}{l}\text { Region in Republic } \\
\text { of Serbia }\end{array}$ & & 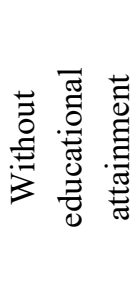 & 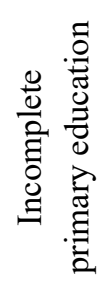 & 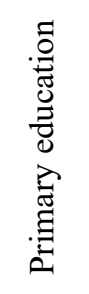 & 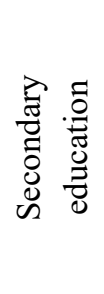 & 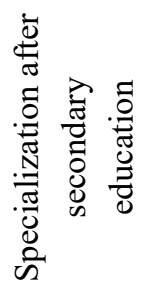 & 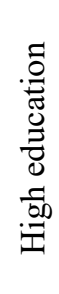 & 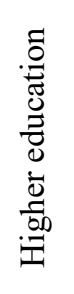 & 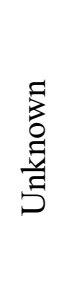 \\
\hline \multirow{3}{*}{ Republic of Serbia } & $\mathrm{t}$ & 2,7 & 11,0 & 20,8 & 48,9 & 0,8 & 5,7 & 10,6 & 0,4 \\
\hline & $\mathrm{m}$ & 1,0 & 8,1 & 20,0 & 54,3 & 1,5 & 5,8 & 10,4 & 0,4 \\
\hline & $\mathrm{f}$ & 4,2 & 13,7 & 21,5 & 43,9 & 0,2 & 5,5 & 10,8 & 0,4 \\
\hline \multirow{3}{*}{ Urban } & $\mathrm{t}$ & 1,5 & 5,5 & 16,0 & 53,4 & 1,0 & 7,5 & 15,7 & 0,4 \\
\hline & $\mathrm{m}$ & 0,6 & 3,1 & 14,2 & 58,2 & 1,8 & 7,8 & 15,7 & 0,4 \\
\hline & $\check{z}$ & 2,2 & 7,6 & 17,6 & 49,2 & 0,3 & 7,3 & 15,7 & 0,4 \\
\hline \multirow{3}{*}{ Other } & $\mathrm{t}$ & 4,4 & 19,0 & 27,7 & 42,4 & 0,6 & 2,9 & 3,2 & 0,4 \\
\hline & $\mathrm{m}$ & 1,6 & 15,0 & 27,9 & 48,9 & 1,1 & 3,1 & 3,1 & 0,4 \\
\hline & $\mathrm{f}$ & 7,3 & 23,0 & 27,5 & 35,8 & 0,1 & 2,8 & 3,2 & 0,5 \\
\hline \multirow{3}{*}{ Beogradski region } & $\mathrm{t}$ & 1,2 & 4,1 & 13,9 & 52,5 & 1,2 & 8,2 & 19,6 & 0,5 \\
\hline & $\mathrm{m}$ & 0,5 & 2,2 & 12,3 & 56,9 & 2,2 & 8,3 & 19,3 & 0,5 \\
\hline & $\check{z}$ & 1,8 & 5,8 & 15,4 & 48,7 & 0,3 & 8,1 & 19,8 & 0,5 \\
\hline \multirow{3}{*}{ Region Vojvodine } & $\mathrm{t}$ & 2,3 & 10,7 & 21,7 & 50,9 & 0,7 & 4,9 & 9,2 & 0,3 \\
\hline & $\mathrm{m}$ & 1,1 & 7,4 & 20,5 & 57,1 & 1,2 & 4,8 & 8,8 & 0,2 \\
\hline & $\mathrm{f}$ & 3,4 & 13,7 & 22,9 & 45,2 & 0,2 & 4,9 & 9,6 & 0,3 \\
\hline \multirow{3}{*}{$\begin{array}{l}\text { Šumadija and } \\
\text { Western Serbia } \\
\text { region }\end{array}$} & $\mathrm{t}$ & 3,4 & 13,9 & 23,4 & 47,2 & 0,8 & 4,7 & 7,0 & $\overline{0,4}$ \\
\hline & $\mathrm{m}$ & 1,0 & 11,0 & 23,1 & 52,6 & 1,5 & 5,0 & 7,0 & 0,3 \\
\hline & $\mathrm{f}$ & 5,7 & 16,7 & 23,7 & 42,1 & 0,2 & 4,5 & 7,0 & 0,4 \\
\hline \multirow{3}{*}{$\begin{array}{l}\text { Region of Southern } \\
\text { and Eastern Serbia }\end{array}$} & $\mathrm{t}$ & 3,8 & 15,0 & 23,3 & 45,0 & 0,7 & 5,1 & 7,4 & 0,5 \\
\hline & $\mathrm{m}$ & 1,4 & 11,3 & 23,0 & 50,5 & 1,3 & 5,5 & 7,7 & 0,5 \\
\hline & $\mathrm{f}$ & 6,0 & 18,5 & 23,7 & 39,6 & 0,1 & 4,6 & 7,0 & 0,5 \\
\hline
\end{tabular}

Not only are there differences between literacy levels among ethnic groupc in Vojvodina, but also there are differences regarding education background. Mostly the Roma population (22.9\%) is without educational background, and then follows the Vlach population $(9.8 \%)$ and the Muslim population (7.6\%). Other ethnic groups have significantly less population with low education levels.

Again the Roma population is the dominating among the group with unfinished primary education $(39.9 \%)$. However, the share of the following populations is significant: Vlach (32.7\%), Romans (23.4\%), Bunjevci (18.2\%), Slovaks (15.8\%), Hungarians and Muslims (15.7\%) and others.
Among the Albanian population, the dominant is the group with unfinished primary education (48.6\%). The smallest share within the population group with finished only primary education belongs to Russians $(11.0 \%)$. The smallest share within the population group with finished only secondary education belongs to the Roma $(9.1 \%)$, and the largest to Yugoslavs (56.4\%), Serbs (53.8\%), Ukrainians (53.5\%), Slovenes (53.2\%), Ruthenians $(52.2 \%)$ and other.

The Russians have the highest share within the group with higher education achieved $(10.3 \%)$, as well as with university education $(28.5 \%)$. All other ethnic groups have a significantly smaller share with a tertiary level of education. 
Table 3: Population aged 15 and above according to ethnicity and educational background (in \%). Source: [10]

\begin{tabular}{|c|c|c|c|c|c|c|c|}
\hline 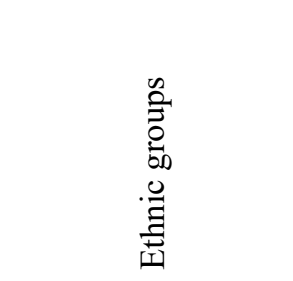 & 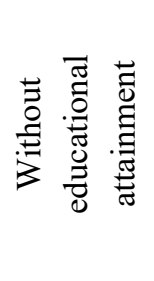 & 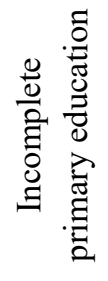 & 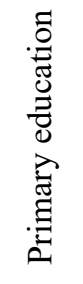 & 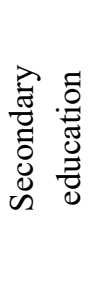 & 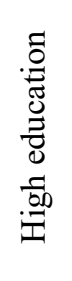 & 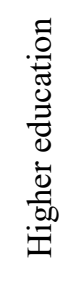 & 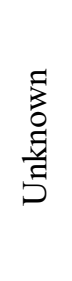 \\
\hline Total & 2,3 & 10,7 & 21,7 & 50,9 & 4,9 & 9,2 & $\mathbf{0 , 3}$ \\
\hline Serbs & 2,2 & 8,8 & 19,6 & 53,8 & 5,3 & 10,2 & 0,1 \\
\hline Albanians & 2,2 & 7,0 & 48,6 & 37,3 & 1,5 & 2,6 & 0,8 \\
\hline Bosniaks & 1,9 & 5,9 & 22,5 & 48,5 & 7,5 & 13,8 & 0,0 \\
\hline Bulgarians & 1,1 & 14,4 & 19,2 & 48,7 & 6,8 & 9,7 & 0,1 \\
\hline Bunjevci & 0,9 & 18,2 & 26,5 & 46,4 & 3,4 & 4,5 & 0,1 \\
\hline Vlachs & 9,8 & 32,7 & 24,8 & 21,6 & 3,9 & 7,2 & 0,0 \\
\hline Goranci & 1,0 & 6,8 & 39,6 & 45,9 & 2,1 & 4,6 & 0,0 \\
\hline Yugoslavs & 0,8 & 5,4 & 18,3 & 56,4 & 6,6 & 12,5 & 0,1 \\
\hline Hungarians & 1,0 & 15,7 & 29,0 & 45,2 & 4,0 & 5,1 & 0,1 \\
\hline Makedonians & 2,3 & 9,9 & 23,7 & 51,6 & 4,6 & 7,8 & 0,1 \\
\hline Muslims & 7,6 & 15,7 & 30,6 & 39,7 & 2,1 & 3,9 & 0,2 \\
\hline Germans & 1,4 & 15,5 & 19,0 & 48,7 & 5,5 & 9,7 & 0,2 \\
\hline Roma people & 22,9 & 39,9 & 27,4 & 9,1 & 0,2 & 0,2 & 0,3 \\
\hline Pomanians & 3,5 & 23,4 & 32,8 & 28,4 & 4,2 & 7,4 & 0,2 \\
\hline Russians & 0,6 & 3,1 & 11,0 & 46,5 & 10,3 & 28,5 & 0,2 \\
\hline Ruthenians & 0,6 & 13,3 & 19,4 & 52,2 & 4,8 & 9,6 & 0,1 \\
\hline Slovaks & 0,8 & 15,8 & 32,1 & 42,2 & 3,5 & 5,5 & 0,1 \\
\hline Slovenians & 0,4 & 6,3 & 19,6 & 53,2 & 7,4 & 13,1 & 0,0 \\
\hline Ukrainians & 2,9 & 12,7 & 18,3 & 53,5 & 4,6 & 7,7 & 0,2 \\
\hline Croats & 2,0 & 14,0 & 23,5 & 48,8 & 4,5 & 7,1 & 0,2 \\
\hline Montenegrins & 1,4 & 5,8 & 14,0 & 55,8 & 7,5 & 15,5 & 0,1 \\
\hline Czechs & 0,5 & 11,1 & 21,4 & 53,2 & 5,7 & 8,1 & 0,0 \\
\hline Other & 3,8 & 9,8 & 20,5 & 42,2 & 5,5 & 15,8 & 2,3 \\
\hline Did not declare & 2,0 & 6,7 & 22,7 & 52,7 & 4,2 & 10,7 & 1,0 \\
\hline Regional affiliation & 0,6 & 4,2 & 15,4 & 58,8 & 6,1 & 14,7 & 0,1 \\
\hline Unknown & 6,0 & 7,5 & 21,2 & 39,4 & 3,2 & 7,3 & 15,4 \\
\hline
\end{tabular}

\section{DISCUSSION}

The level of education background depends on the social status of an individual and then whole families. However, this population structure is also influenced by heritable factors. As a result, the ethnic groups which had a higher share in the groups of lower education levels in the past still have a higher share. On the other hand, the ethnic groups that had larger numbers of the highly educated populations remained with larger numbers. The Russians are a prominent population group in Vojvodina for their highest education level. Observing the whole territory of Serbia, there are more educated populations than the Russians (38.0\%), first the Jewish population (50.2\% highly educated) and then follows the Armenian population $(44.0 \%)$. As was cited in the introduction, the Jewish population has the highest education level in the world. However, the Russians, as highly educated population, were arriving in this area after the October Revolution when doctors, architects, professors, lawyers and university professors, teachers and other educated people fled from the communist regime. A certain number of them settled in the former Kingdom of Serbs, Croats, and Slovenes.

Their descendants continued the education tradition to the present time and most of them gained university education [11] [12] [13]. More Russian population arrived during the last decades to this area due to the problems in the border region with Ukraine but also due to Russian companies that started doing business here. Among them, the most significant is Gaspromneft - Oil Company. On the other hand, certain ethnic groups such as the Roma 
and the Vlach have an extremely poor educational structure for the century, we live in. It is a serious threat to their social integration, and especially difficult issues regarding their position at the job market [14]. The Roma children who are excluded from the education system may create a serious issue with long term consequences on future

\section{CONCLUSION}

Ethnic variety and versatility is the wealth of Vojvodina. In order to sustain and improve the wealth, it is necessary to preserve the presence of all ethnic groups that survived in the area despite numerous problems that occurred in the previous centuries. Each ethnic group has its own ethnicdemographic characteristics which they managed to preserve. These are the key issues that together with the highest possible educational level of the population may contribute to advancement and prosperity in the area. For the time being, the educational structure of the population in Serbia and in Vojvodina is far from ideal. All ethnic groups with the largest numbers of population have achieved only the secondary education level. If the share of the population with secondary education generations that will continuously create the illiterate and socially unadjusted generations. Therefore, the problem of inclusion of the Roma into the educational system is one of the burning issues regarding social mobility, social integration and national emancipation [15].

decreases, then the share of the population with primary education increases. The only exception to the rule is the Russian population group in which every third person has completed tertiary education. If the situation had been similar for all other ethnic groups, it would have been more favorable for the economic status of Serbia as well as for its accession to the European Union.

The population with tertiary education level generally finds jobs easily, therefore the increase in the share of the population with university education leads to an increase in the employment rate. For all those reasons, the country should invest in preserving the sustainability of all ethnic groups, and make every effort to provide a tertiary level of education for more people.

\section{REFERENCES}

[1] Hanushek, E \& Wossemann, L. 2010. How much do educational outcomes matter in OECD countries? National Bureau of Economic Research.

[2] Hanushek, E. \& Wossmann, L. 2007. The Role of Education Quality in Economic Growth. World Bank Policy Research Working Paper 4122.

[3] Statistical Office of the Republic of Serbia, 2019, https://www.stat.gov.rs/, accessed 1 february 2020.

[4] http://www.oecd.org/education/ accessed 4 february 2020

[5] https://ourworldindata.org/tertiary-education

[6] https://www.pewforum.org/2016/12/13/religion-and-education-around-the-world/religioneducation_schooling/ accessed 4 february 2020

[7] Statistical Office of the Republica of Serbia, 2013, Educational attainment, literacy and computer literacy. 2011 Census of Population, Households and Dwellings in the Republic of Serbia.

[8] Lakčević, S., Đorđević, Lj., Đurđev, B., Arsenović, D., Marinković, I., Rašević, M., Nikitović, V., PredojevićDespić, J., Penev, G., Šobot, A., Stanković, B., Radivojević, B. 2015. Populacija Srbije početkom 21. veka (The population of Serbia at the beginning of the 21st century). 2011 Census of Population, Households and Dwellings in the Republic of Serbia.

[9] Cvjetičanin, S. \& Živanović V. 2012. Zastupljenost romske djece u obrazovnom sustavu Srbije. Napredak: Časopis za interdisciplinarna istraživanja u odgoju i obrazovanju, Vol. 153, No. 1, str. 53-76.

[10] Statistical Office of the Republic of Serbia, Population Census 2011, additional data processing.

[11] Bubalo-Živković, M. \& Đerčan, B., 2018. Selected indicators of population development - Russian population in Vojvodina. In: Ethnic groups at the beginning of the 21st century. Edited by: Tamara Lukić and Aleksandra Terzić. University of Novi Sad, Faculty of Sciences, Departmen of Geography, Tourism and Hotel Management, p 85-99.

[12] Bubalo Živković, M., Lukić, T., Đerčan, B., Kalenjuk, B., 2018, Demographic characteristics of Russians - the immigration ethnic group in the Regiona of Vojvodina (Serbia). Practical Geography and XXI Century Challenges, The 2018 Thematic Conference dedicated to the centennial of the Institute of Geography of Russian Academy of Sciance, Conference book, part 2, 4-6 June 2018, Moscow, p 194. 
[13] Jovanović-Kranjec, M., 2013, Ekonomizacija visokog obrazovanja u Republici Srbiji. Ekonomski horizonti. JanuarApril, XV, 1, str. 87-96.

[14] Đurić, V., Tanasković, D, Vukmirović, D., Lađević, P. 2014. Etnokonfesionalni jezički mozaik Srbije. Popis stanovništva, domaćinstava i stanova 2011. u Republici Srbiji, Republički zavod za statistiku, Beograd.

[15] Mandić, I. 2012. Problem obrazovanja Roma u Srbiji. Norma, vol. 17, br. 2, str. 247-256) 